\title{
Dejima VOC dan rangaku
}

\author{
BAMBANG WIBAWARTA
}

\begin{abstract}
ABSTR ACT
Japan and the Netherlands have maintained a special relationship for about 300 years since the adoption of the National Seclusion policy, the so-called sakoku by the Tokugawa shogunate (1603-1867). The Dutch began trading with Japan and engaging with Japanese society in 1600, when a Dutch ship, De Liefde, arrived in Kyushu. The Tokugawa government measures regarding foreign policy included regulations on foreign access to Japan and a prohibition on Japanese going abroad. Between the middle of the seventeenth to the early nineteenth century, Japan was characterized by a stable political pattern in which representatives of the VOC (Dutch East India Company), were the only Europeans with a right to trade in Japan. In the course of this period, the Japanese evaluation of the Dutch changed from regarding them as commercial agents to seeing them as importers of European knowledge. This paper is especially concerned with the influence of the so-called 'Dutch Studies' (rangaku) on the early modernization of Japan, especially with regard to medicine and the natural sciences. This research examines the development of rangaku and the trading between Japan and VOC at Dejima.

KEYWORDS

Rangaku (Dutch learning), Dejima, Hirado, VOC, Tokugawa, hegemoni (hegemony).
\end{abstract}

Meskipun Jepang melakukan sakoku (politik menutup negeri dari bangsa asing) selama kurun waktu 1639-1853 di era Tokugawa (1603-1867)1, mereka tetap menjalin hubungan dagang dengan negara lain, yakni Cina dan Belanda. Permasalahan ini sangat penting untuk diangkat, pertama, untuk menjelaskan

1 Di era Tokugawa diterapkan sistem stratifikasi sosial yang kerap disebut shinokosho, bertujuan agar kelas militer (bushi, atau samurai) berkuasa terus secara turun-temurun. Kata shinokosho merupakan kependekan dari shi, dari kata bushi (samurai), no kependekan dari noumin (petani), ko dari kosakunin (atau kelas pengrajin), dan sho yang merupakan kependekan Shounin (kelas pedagang). Urutan ini dibuat oleh kelas samurai yang berkuasa berdasarkan kontribusinya terhadap penguasa (kelas samurai).

BAMBANG WIBAWARTA adalah pengajar Program Studi Jepang, Fakultas Ilmu Pengetahuan Budaya, Universitas Indonesia. Ia memiliki perhatian dan minat penelitian pada kesusastraan dan masyarakat Jepang. Beberapa tema penelitiannya adalah mengenai kesusastraan Jepang Era Meiji (1868-1912) dalam kaitannya dengan modernisasi dan kaum cendekiawan. E-mail: bambangwibawarta@hotmail.co.jp. 
bahwa selama menerapkan politik pintu tertutup Jepang tetap menjalin hubungan dengan luar negeri meskipun dalam skala sangat terbatas. Kedua, membuktikan bahwa pengaruh asing selain Cina, khususnya pengaruh Barat sudah mulai merasuk ke Jepang jauh sebelum Restorasi Meiji (1868) dilaksanakan. Selain itu mempertegas bahwa di masa Tokugawa Jepang berarti tidak hanya menyerap kebudayaan Cina, seperti Konfusianisme yang kemudian berkembang dan berpengaruh luas dalam berbagai aspek di Jepang pada masa itu, namun juga telah menerima pengaruh ilmu pengetahuan, pemikiran dan kebudayaan Barat.

Pada masa awal sakoku diterapkan, bangsa Barat yang boleh masuk ke wilayah Jepang hanyalah Belanda. Tidak hanya dalam rangka hubungan dagang, Belanda menjadi satu-satunya negara Barat yang menjadi penyuplai pengetahuan ke Jepang. Hal ini disebut dengan rangaku², yakni ilmu pengetahuan dari Belanda. Sebenarnya ilmu pengetahuan Barat yang masuk ke Jepang pada masa itu tidak hanya rangaku, namun ada juga yang disebut nambangaku, yakni ilmu pengetahuan Barat yang disebarkan melalui Siam, Luzon, dan Jawa oleh orang-orang Portugis, Spanyol, dan Italia ke Jepang. Namun demikian, yang paling dikenal dan identik dengan ilmu pengetahuan Barat adalah rangaku, yang dalam praktiknya tidak hanya pengetahuan dari Belanda saja. Hal ini tidak mengherankan mengingat kesempatan berdagang selama masa sakoku hanya diberikan kepada Belanda. Dalam makalah ini akan dibahas mengenai hubungan perdagangan antara Jepang dan VOC (Vereenigde Oost-Indische Compagnie), dan pengaruh rangaku yang dibawa VOC pada era Tokugawa di Jepang.

\section{SAKOKU: MISIONARIS DAN MASUKNYA VOC}

Pada zaman Tokugawa ${ }^{3}$ agama Kristen Katolik yang disebarkan bangsa Portugis dilarang karena dianggap sebagai ancaman bagi pemerintahan bakufu (pemerintahan militer), yakni berpotensi mengurangi loyalitas masyarakat dan wibawa penguasa, juga sudah mulai menyentuh ranah politik. Ada dua hal yang menyebabkan pelarangan terhadap agama Kristen Katolik, pertama adalah bersifat ideologis dan kedua adalah masalah politik praktis. Kekristenan dianggap dapat mengganggu otoritas bakufu karena masyarakat akan memiliki alternatif lain selain yang saat itu ada dalam tradisi Jepang dan bakufu, dan individu akan menjadi mandiri. Hal ini dikhawatirkan akan berpengaruh pada wibawa penguasa, sedangkan untuk mempersatukan negara rezim Tokugawa membutuhkan loyalitas penuh dari warganya. Sedangkan penganut agama Buddha dibiarkan karena mereka telah diterima dan berakar di Jepang sudah sejak lama, serta tidak terlalu berpengaruh pada tataran politis. Di samping itu, karena Shogun ${ }^{4}$ Toyotomi Hideyoshi juga menganggap posisi agama

$2 \quad$ Rangaku merupakan kependekan dari Oranda gaku. Oranda berarti Belanda, sedangkan gaku memiliki makna ilmu pengetahuan.

3 Kerap juga disebut dengan zaman Edo, karena ibukota pada saat itu terletak di Edo, yang saat ini disebut Tokyo.

$4 \quad$ Penguasa tertinggi militer. Shogun memiliki bawahan yang menguasai wilayah tertentu, yang disebut daimyo (tuan tanah). Sedangkan samurai adalah pengikut setia para daimyo. 
Buddha lemah dan mudah diatasi. Agama Buddha sendiri diperkenalkan di Jepang sekitar abad keenam yang kemudian berkembang menjadi sekte-sekte, seperti sekte Dojo pada sekitar abad kedelapan dan sekte Zen pada sekitar abad kedua belas.

Awalnya agama Kristen diperkenalkan oleh misionaris Jesuit Spanyol bernama Francisco Xavier yang tiba di Kagoshima, Jepang pada Agustus 1549 bersama dua orang misionaris lainnya. Keshogunan Oda Nobunaga membiarkan aktivitas misionaris di Kyoto, ibukota Jepang, bukan karena ia tertarik dengan ajarannya, tetapi lebih karena hendak memanfaatkannya sebagai alat melawan para pembesar beragama Buddha yang menjadi rintangan dalam upaya mempersatukan Jepang. Ia memberi dukungan kepada gereja katolik dalam bentuk perlindungan dan materi. Setelah Nobunaga terbunuh pada tahun 1582, aktivitas gereja katolik mengalami kemunduran.

Ketika kekuasaan beralih pada Toyotomi Hideyoshi (1582-1598) sikap anti Barat mulai muncul. Sebenarnya Hideyoshi tidak terlalu mempermasalahkan perkembangan dan aktivitas misionaris kristen. Ia masih menginginkan para pedagang tetap tinggal di Jepang dan para pendeta saja yang diusir, karena ia masih mengharapkan pajak dari perdagangan dengan bangsa Portugis. Ia juga berupaya memperalat gereja Katolik untuk kepentingan politiknya, yakni merebut wilayah Kyushu dari klan Shimazu. Kyushu sangat strategis, karena dapat menjadi jembatan perdagangan ke Cina dan negara Asia lainnya, termasuk Asia Tenggara. Di wilayah Kyushu gereja Katolik cukup berpengaruh. Ada kecenderungan bahwa pendeta tidak hanya sebagai pemimpin spiritual tetapi juga menjadi pemimpin politik. Hal ini membuat Hideyoshi berubah pikiran, karena ia melihat adanya campur tangan gereja dalam urusan politik dalam negeri Jepang. Terlebih setelah ia mendapatkan adanya usaha kristenisasi yang dilakukan secara paksa di daerah Kyushu, ia pun mengeluarkan peringatan pada 23 Juli 1587, dan memerintahkan misionaris Jesuit meninggalkan Jepang dalam dua puluh hari. Ternyata dekrit ini kurang efektif. Meskipun sejumlah gereja dihancurkan, tetapi tetap saja jauh lebih banyak misionaris yang datang daripada yang pergi meninggalkan Jepang. Masalah ini menjadi kian bertambah rumit ketika pada Agustus 1596 kapal perang Spanyol San Felipe merapat di Pulau Shikoku, yang berada di tenggara Jepang dalam pelayarannya dari Filipina menuju Acapulco. Melihat kapal-kapal yang dilengkapi persenjataan ini Toyotomi Hideyoshi menjadi lebih berhati-hati terhadap bangsa Eropa, karena ia mengetahui bahwa belum lama sebelumnya Filipina ditaklukkan Spanyol. ${ }^{5}$

Kedatangan bangsa Portugis ke Tanegashima, Kyushu, pada tahun 1543 merupakan awal dimulainya hubungan Jepang dengan Barat. Mereka selain berdagang, juga menyebarkan agama Kristen dan sekaligus memperkenalkan senjata api. Dengan demikian, pada masa ini pulalah Jepang mulai mengenal ilmu pengetahuan Barat. Meskipun Jepang kemudian menolak penyebaran

5 Ordo Fransiskan kemudian dituduh sebagai mata-mata Spanyol, dan Hideyoshi pun memperbaharui dekritnya mengenai agama Kristen. Pada 5 Februari 1597, 26 orang warga Kristen dibunuh di bukit Nishizaka, Nagasaki, atas perintah Hideyoshi sebagai peringatan bagi penganut agama Kristen. 
agama Kristen Katolik oleh bangsa Portugis, mereka mengambil keuntungan dengan menyerap ilmu pengetahuan Barat melalui rangaku yang dibawa VOC. Dalam rangaku banyak pengetahuan yang berkaitan dengan teknologi yang dapat dimanfaatkan untuk memperkuat posisi bakufu atau keshogunan. Pemerintah bakufu sangat sadar bahwa mereka membutuhkan alat atau media untuk mengukuhkan hegemoni kelas samurai (bushi). Meskipun demikian, Jepang tetap waspada terhadap agama Kristen, sehingga mereka membatasi ruang lingkup ilmu pengetahuan yang mereka inginkan dan membatasi ruang gerak orang-orang Belanda. Setelah hubungan dengan Portugis ditutup sepenuhnya, para pedagang Cina dan VOC dibatasi hanya boleh berdagang di Nagasaki. Belanda menjadi satu-satunya negara Eropa yang berhubungan secara langsung dengan Jepang hingga dilakukannya kaikoku ${ }^{6}$, atau pembukaan negeri.

Kekhawatiran penguasa ketika itu cukup beralasan, yakni karena Jepang pernah mengalami kekacauan yang disebut dengan Sengoku Jidai ${ }^{7}$, atau era perang saudara selama lebih dari seratus tahun. Dalam situasi seperti itu muncul usaha untuk menyatukan kembali negara melalui tiga orang tokoh besar, yakni Oda Nobunaga (1534-1582), Toyotomi Hideyoshi (1536-1598), dan Tokugawa Ieyasu (1543-1616). Oda Nobunaga terbunuh sebelum cita-citanya mempersatukan Jepang tercapai, dan usaha ini berhasil dilakukan penerusnya, Toyotomi Hideyoshi, yang kemudian dilanjutkan oleh Tokugawa Ieyasu.

Berdasarkan uraian tersebut jelas sekali bahwa untuk mengukuhkan hegemoni Tokugawa beserta kelas samurai, pemerintahan bakufu mengusir Portugis, dan melihat bahwa berhubungan dengan Belanda lebih aman. Jika dilihat lebih jauh, sakoku, atau penerapan politik pintu tertutup dapat dibaca sebagai upaya untuk melanggengkan hegemoni kelas samurai, dengan menutup akses kepada dan dari pihak Barat. Masyarakat tidak diberi pilihan lain. Antonio Gramsci (1971: 79) berpendapat bahwa praktik kekerasan dan paksaan oleh negara hanya bisa dibenarkan jika tindakan itu mendapatkan legitimasi dari kesepakatan mayoritas. Sedangkan di Jepang, pemerintah bakufu secara sepihak membuat stratifikasi sosial,

$6 \quad$ Dimulai dengan kedatangan Komodor Perry dari Amerika yang membawa empat kapal perang pada tahun 1853, Jepang yang semula menerapkan sakoku (penutupan negeri dari bangsa asing, khususnya Barat) kemudian melakukan kaikoku yang puncaknya adalah Restorasi Meiji (1868). Sejak Restorasi Meiji pengaruh Barat masuk ke Jepang dengan derasnya. Jepang bagaikan terbangun dari tidur panjang dalam sakoku selama sekitar 250 tahun, dan merasa tertinggal dari bangsa Barat. Jepang merasa harus mengejar ketertinggalannya dan berusaha menyejajarkan diri dengan bangsa Barat dengan cara Barat, yakni memajukan teknologi dan memperkuat militer. Jepang pun mengumandangkan slogan fukoku kyohei, yang artinya negara kaya, militer kuat. Tetapi hal ini pulalah yang menyeret Jepang terlibat dalam dua perang besar dengan Cina (1894-1895) dan Rusia (1904-1905).

Periode sekitar pertengahan abad lima belas hingga awal abad tujuh belas di Jepang, di mana terjadi kekacauan sosial, banyak intrik politik, dan kerap terjadi konflik militer. Selain terjadi bencana alam seperti gempa bumi yang mengakibatkan kelaparan, juga terjadi ketidakstabilan yang dipicu oleh kaum petani yang tidak puas dengan sistem perpajakan. Hal ini menjadi lebih runyam dengan terjadinya perang Onin (Onin no ran, 1467-1477) yang menyebabkan kemunduran ekonomi sangat besar. Perang ini dipicu oleh suksesi keshogunan yang tidak berjalan baik sehingga terjadi perang di sekitar Kyoto yang menjalar ke provinsi sekitarnya antara militer kelompok barat klan Hosokawa dan kelompok timur dari klan Yamana. 
dengan mendudukkan bushi (kelas militer) pada posisi paling atas. Usaha untuk mempersatukan negara oleh ketiga pemimpin tersebut, sekaligus melanggengkan kepemimpinan militer oleh keluarga Tokugawa. Gramsci mengungkapkan tentang bagaimana berbagai ideologi di dalam suatu negara kemudian bersatu, mengendap, dan kemudian menjadi universal di dalam ideologi hegemoni negara (hegemonic ideology of the state), tetapi yang terjadi di Jepang dengan sakoku dapat dilihat sebagai usaha kaum samurai memperluas kepentingan mereka, sehingga dapat dikatakan sebagai passive revolution, yakni revolusi yang hanya dijalankan oleh sebagian kelas sosial, terutama kelas-kelas sosial yang dominan dan memegang hegemoni. Dengan demikian terjadi dominasi sosial, di mana hegemoni kelas samurai semakin kuat. Fenomena semacam ini disebut Gramsci sebagai historical block (Gramsci 1971: 366 ). Hal ini mirip dengan yang dijelaskan Bourdieu (1990: 192) dengan teori dominasi simboliknya. Ia berupaya menjelaskan bagaimana kelompokkelompok subaltern pada akhirnya memeluk budaya dominan, dan sekaligus mengabaikan budaya mereka sendiri. Meskipun budaya kaum petani, pengrajin, dan kota tidak hilang, namun spirit yang dikumandangkan kaum samurai terus mengumandang dan tertanam dalam, seperti etos bushido dan sebagainya hingga hari ini di Jepang. Bourdieu menjelaskan masalah dominasi sosial semacam ini dengan sangat baik.

Dalam bahasa lain dari Bourdieu dan Passeron (1990) kelas samurai memiliki cultural capital untuk melakukan hal tersebut, sehingga kelas lain menerima stratifikasi sosial yang dibuat kelas samurai. Kelas lainpun menerima transmisi pengetahuan dari kelas samurai dari generasi ke generasi yang mengukuhkan dominasi kelas penguasa. Habitus yang secara perlahan dan sistematis ditebar oleh kaum samurai yang dipadukan dengan capital itulah yang memungkinkan praktik sosial itu terjadi. Jelaslah sebagaimana diungkapkan Foucault (1977) bahwa kebenaran merupakan konstruksi wacana yang dibingkai oleh sistem pemikiran (episteme) tertentu dan dikendalikan oleh kekuasaan.

Tokugawa Ieyasu ${ }^{8}$ yang berkuasa mulai tahun 1600 pada mulanya masih berniat untuk bersikap toleran terhadap kehadiran para misionaris Katolik, karena ia masih mengharapkan keuntungan melalui perdagangan dengan Portugis. Kedatangan kaum protestan Belanda dan para pedagang Inggris membuat ia punya pilihan untuk tidak tergantung pada pedagang Portugis. Ieyasu kemudian berubah menentang kekristenan (Katolik), seperti pendahulunya. Pada tahun 1614 para misionaris diperintahkan untuk meninggalkan Jepang, kebanyakan dari mereka diusir, akan tetapi 40 orang di antaranya termasuk penginjil keturunan Jepang masih diperbolehkan tetap tinggal.

Hubungan Jepang dengan Belanda dimulai tahun 1600, ketika kapal Belanda De Liefde dengan 24 orang awaknya (lihat Ilustrasi 1), dihantam badai dan terdampar di Teluk Usuki, Kyushu. Mereka diterima dengan baik oleh daimyo (tuan tanah) Otomo Yoshimune, bahkan William Adams

$8 \quad$ Pembahasan mengenai pemerintahan Tokugawa Ieyasu dapat dilihat dalam Conrad Totman (1988). 
dan beberapa orang awaknya diberi kedudukan terhormat, yakni dijadikan penasehat perdagangan luar negeri, dan Jan Josten van Lodenstijn dijadikan penasehat dalam pembuatan peta dan pembuatan kapal. Sebenarnya tujuan kedatangan mereka adalah untuk mengadakan hubungan dagang dengan Asia Timur setelah mendengar keberhasilan ekspedisi Cornelis de Houtman ke Jawa dan Sumatera (Goodman 1986: 9). Dari merekalah Ieyasu mengetahui sikap kaum Protestan terhadap gereja Roma Katolik. Ieyasu pun tidak perlu khawatir dengan pengusiran para pendeta yang dianggapnya berbahaya akan mengganggu perdagangan.

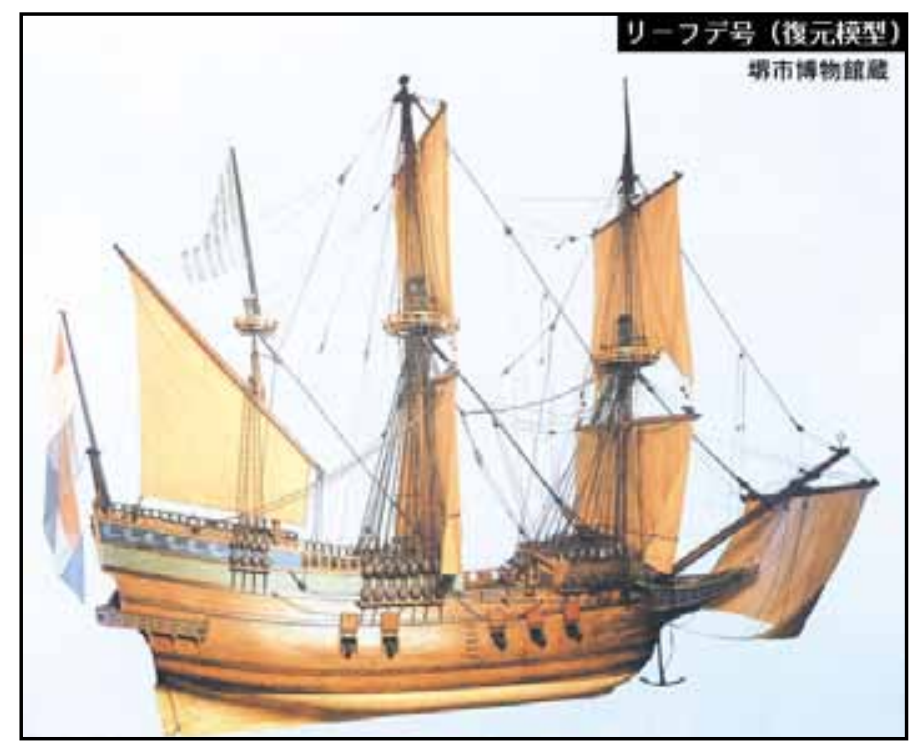

Ilustrasi 1: Miniatur kapal De Liefde. Sumber: Laman Museum Yodogawa di Sakai-shi, Osaka. ${ }^{9}$

Hubungan diplomatik Belanda dengan Jepang dimulai tahun 1608, yakni pada masa pemerintahan Tokugawa Ieyasu. Kebijakan penguasa Jepang ketika itu adalah dengan membatasi misionaris Kristen dan memajukan perdagangan. Portugis dan Spanyol dipaksa meninggalkan pelabuhan Dejima di Nagasaki, karena mereka menyebarkan agama Kristen dibalik pelayanan kesehatan, dan mereka diisukan sedang berupaya untuk menguasai Jepang. Kekristenan dipandang sebagai penyebab kurang berfungsinya elemenelemen masyarakat yang tentunya akan pula melemahkan wibawa penguasa. Penekanan Kristen atas kesadaran individual dipandang sebagai subversif, karena mengganggu persatuan yang menuntut pengabdian tidak bersyarat atau total pada penguasa.

Sejak resmi diizinkan, bangsa Belanda mulai mengunjungi Jepang secara teratur dan mendirikan pos dagang tetap di Hirado. Tokugawa Ieyasu awalnya lebih mementingkan perdagangan dengan Eropa karena dianggap

9 http://www.yodo-museum.go.jp/kikaku/kikaku04/kika4_02.html. Diakses pada tanggal 27 Juni 2008. 
menguntungkan daripada memperhatikan agama Kristen. Tanpa disadari hal ini menyebabkan agama Kristen berkembang luas. Ieyasu yang sedang mengumpulkan kekuatan dan menuntut loyalitas para daimyo (tuan tanah) atau penguasa daerah merasa khawatir dan menganggap agama Kristen sebagai ancaman. Sehingga ia mengeluarkan larangan bagi propaganda agama Kristen dan memperketat perdagangan. Larangan tersebut diteruskan oleh Tokugawa Iemitsu (1603-1651) yang mencanangkan kebijakan sakoku pada tahun 1639, juga melarang kapal Portugis dan Spanyol berlabuh di Jepang. Dengan demikian, berakhirlah hubungan Jepang dengan Portugis setelah berjalan hampir 100 tahun. Pada tahun 1641, pos dagang Belanda di Hirado dipindahkan ke pulau Dejima, Nagasaki, dan merupakan satu-satunya pelabuhan terbuka yang hanya diperuntukkan bagi Cina dan Belanda untuk perdagangan luar negeri. ${ }^{10}$ Rezim Tokugawa merasa lebih aman berhubungan dengan Belanda (VOC) daripada Portugis yang menyertakan misi penyebaran agama dalam hubungannya dengan Jepang. Sekali lagi pemerintahan bakufu tidak ingin hegemoninya digoyang oleh agama Katolik.

Dalam hegemoni, kelompok yang mendominasi berhasil mempengaruhi kelompok yang didominasi untuk menerima nilai-nilai moral, politik, dan budaya dari kelompok dominan. Pada masa ini kondisi negeri Jepang relatif aman, karena tidak lagi terjadi perang saudara. Para samurai yang tadinya sibuk berperang, dikhawatirkan akan menjadi kekuatan yang mengganggu penguasa. Maka dengan sistematis penguasa mewajibkan para samurai untuk mempelajari etika Konfusius yang di antaranya mengajarkan kesetiaan dan loyalitas pada atasan, serta menghormati hubungan atasan-bawahan (shuju kankei). Inilah yang ditanamkan penguasa. Nilai-nilai moral ini kemudian menyebar dan dianut segenap lapisan masyarakat. Hegemoni diterima sebagai sesuatu yang wajar, sehingga ideologi kelompok dominan dapat menyebar dan dipraktikkan.

Para pedagang Portugis dianggap penguasa membantu aktivitas para misionaris. Sedangkan tujuan bangsa Belanda (VOC) ke Jepang hanya untuk berdagang. Selain itu, agama Kristen yang dianut bangsa Belanda adalah Kristen Protestan bukan Katolik seperti yang disebarkan para misionaris Portugis. Ketika terjadi pemberontakan Shimabara (1637-1638) yang dilakukan para petani beragama Katolik, pemerintah bakufu meminta bantuan Belanda, sekaligus untuk menguji loyalitas Belanda (Nakamura 1970: 1-21). Belanda yang merasa khawatir dan dalam bahaya jika tuntutan itu tidak dipenuhi, lantas memihak Jepang yang anti Kristen. Para petani yang dibantu orang Portugis dan Spanyol akhirnya kalah, dan semenanjung Shimabara jatuh ke tangan bakufu. Akibatnya orang Portugis dan Spanyol diusir dari Jepang pada 1639, dan selanjutnya Jepang menerapkan sakoku. Hanya orang Belanda di antara orang-orang Eropa yang diperbolehkan tetap tinggal di Jepang, itupun dilokalisisasi.

10 Nishi Kazuo (2004) mengulas cukup baik aktivitas VOC dan para petugas bakufu yang keluar masuk Dejima, juga tentang wanita penghibur di wilayah tersebut. 


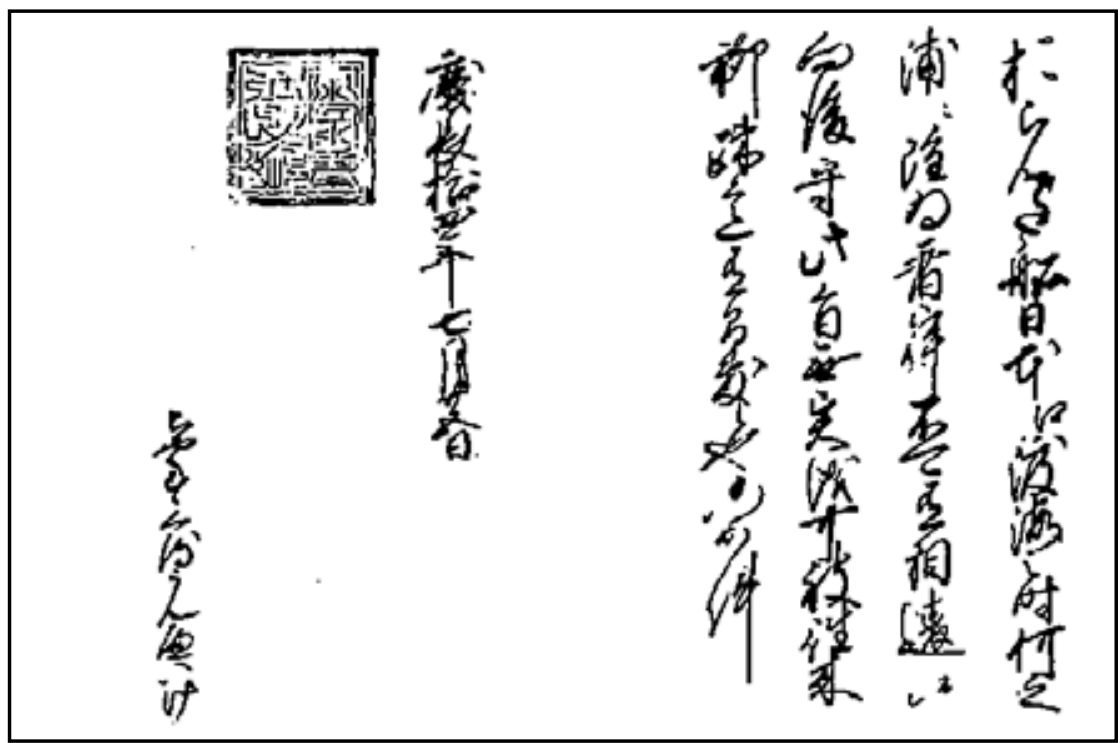

Ilustrasi 2: Surat izin dagang dari Tokugawa Ieyasu. ${ }^{11}$

Sebenarnya Iemitsu ragu dengan kehadiran Belanda di Jepang, namun karena Ieyasu mendukung perdagangan dengan Belanda (lihat Ilustrasi 2) maka ia melanjutkannya, seperti yang tercantum dalam kutipan di bawah ini.

His majesty (the shogun) charges us to inform you that it is of slight importance to the empire of Japan whether foreigners come or do not come to trade; but in consideration of the chartergranted them by Ieyasu, he is pleased to allow the Hollanders to continue their operations and to leave them their commercial and other privilages, on the condition that they evacuate Hirado and establish themselves and their vessel in the port of Nagasaki. (Goodman 1986: 15).

Belanda akhirnya menyadari bahwa kebijakan Iemitsu merupakan bentuk kompromi antara yang pro dan anti orang asing, dan mereka diharuskan tinggal di Pulau Dejima. Sebenarnya Dejima bukan tempat yang nyaman bagi para pedagang VOC, terlebih karena mereka diawasi dengan ketat oleh otoritas setempat. Hal ini dimaksudkan untuk mencegah masuknya kembali agama Kristen, dan mencegah penyelundupan yang dapat mengakibatkan perlawanan bersenjata dari Belanda yang memiliki persenjataan lebih modern.

Dalam perjalanannya dari interaksi dengan bangsa Belanda tersebut, memunculkan minat bangsa Jepang terhadap ilmu pengetahuan Barat, misalnya dalam bidang kedokteran, astronomi, juga persenjataan melalui rangaku.

$11 \quad$ Dikutip dari Huibert (1984: 28). Inti dari surat tersebut adalah bahwa Jepang tidak keberatan jika ada kapal Belanda yang berlabuh di pantai manapun di Jepang. Peraturan ini berlaku di seluruh wilayah Jepang tanpa keberatan apapun dari Jepang, dan Jepang harus menunjukkan sikap bersahabat kepada Belanda. 


\section{RANGAKU DAN RELASI KEKUASAAN JEPANG-VOC}

Akibat diterapkannya sakoku, informasi mengenai ilmu pengetahuan, politik, kebudayaan, dan perdagangan dari negeri Barat ke Jepang hanya dapat disampaikan oleh orang-orang Belanda melalui media bahasa Belanda. Oleh masyarakat umum hal ini dianggap sebagai ilmu pengetahuan Belanda yang disebut rangaku, meskipun sebenarnya ini mengacu pada ilmu pengetahuan dari Eropa secara umum. Rangaku selanjutnya berkembang luas sehingga berperan besar dalam perkembangan ilmu pengetahuan alam di Jepang, seperti bidang astronomi dan ilmu kedokteran. Rangaku mencapai puncaknya pada era pemerintahan Shogun Tokugawa Yoshimune (1684-1751). Jepang sangat peduli terhadap masalah kesehatan sehingga menganggap penting ilmu kedokteran. Astronomi dipandang amat penting untuk membuat sistem kalender yang berguna bagi pertanian. Sedangkan penelitian di bidang lain seperti hukum, sejarah, sastra, dan agama pada awalnya dilarang karena dikhawatirkan akan menjadi media masuknya kembali agama Kristen yang dianggap dapat mengganggu otoritas penguasa.

Pada era ini pengetahuan Barat masuk ke Jepang hanya melalui Belanda, informasi tentang Jepang juga masuk ke Barat dari kantor VOC di Jepang saja. Beberapa orang ilmuwan Barat tentang Jepang, misalnya Engelbert Kaempfer (1651-1716, penulis The history of Japan pada tahun 1727, dan dicetak ulang pada tahun 1906), Carl Peter Thunberg ${ }^{12}$ (1743-1828, penulis mengenai flora Jepang, di antaranya Flora Japonica (1784), Icones plantarum japonicarum (1805)), dan lainnya semua adalah pegawai kantor VOC di Jepang.

Karena adanya pembatasan seperti itu, anggapan masyarakat umum terhadap rangaku adalah sebagai ilmu terapan, atau jitsuyougaku, atau juga ilmu pengetahuan yang bersifat teoritis (jitsurigaku). Oleh karena itu, pada awal zaman Meiji (1868-1912) Fukuzawa Yukichi ${ }^{13}$ (1835-1901) mengungkapkan bahwa yang penting bagi Jepang adalah jitsugaku, yakni ilmu pengetahuan yang dapat berguna langsung bagi kehidupan masyarakat, dalam hal ini adalah ilmu pengetahuan praktis dari Barat, sedangkan yang datang dari Cina diungkapkannya sebagai pengetahuan semu dan ia meragukannya (Numata Jiro et al. 1976: 613).

Peran Shogun Yoshimune terhadap perkembangan rangaku sangat besar karena ia berpikir bahwa hal ini dapat memberi kontribusi terhadap kemajuan Jepang. Ia menghapuskan larangan mengimpor dan pembatasan penerjemahan buku-buku berbahasa Belanda. Ia pun mendukung pembukaan sekolah-sekolah yang mengajarkan bahasa Belanda dan rangaku, seperti bidang astronomi, bahkan pada tahun 1720 ia memerintahkan pembangunan lembaga

12 Tidak semua ilmuwan yang datang dengan nama VOC berkebangsaan Belanda. Kaempfer adalah bangsa Jerman dan Thunberg berkebangsaan Swedia.

13 Fukuzawa Yukichi adalah Bapak Pendidikan, pendiri Universitas Keio, Jepang. Pemikirannya tentang pemerintahan dan institusi sosial sangat berpengaruh pada perubahan cepat diberbagai bidang pada era Meiji. Ia pun belajar rangaku, dan pernah dikirim ke San Fransisco tahun 1860 sebagai anggota delegasi Shogun. Beberapa di antara karya terkenalnya adalah Seiyou Jijou (Kondisi di Barat) yang terbit 10 volume tahun 1867,1868, dan 1870. Sedangkan Gakumon no Susume (1872-1876) yang terbit 17 volume merupakan karyanya yang menjadi best seller di Jepang pada masa itu, dan masih terus dibaca dan dibahas hingga kini. 
riset dengan peralatan dari Barat untuk mempelajari sistem penanggalan masehi. Salah seorang tokoh terkenal yang belajar ilmu astronomi dari terjemahan buku-buku Belanda adalah Asada Goryu (1743-1799). Ia mendapat tugas dari pemerintah bakufu untuk memperbaiki sistem penanggalan menggunakan sistem Barat. Akhirnya Goryu dapat menyelesaikan tugasnya pada tahun 1798, dengan sistem penanggalan yang disebut sebagai kalender zaman Kansei. Dapat pula disebutkan beberapa tokoh lainnya yang belajar dari rangaku seperti Aoki Konyo (1698-1769) yang menerbitkan kamus Jepang-Belanda pada tahun 1745, dan Ajima Naonobu (1739-1798) adalah ahli matematika yang pertama kali memperkenalkan penggunaan integral dan diferensial kalkulus, serta logaritma. Tokoh lainnya adalah Hiraga Gennai (1728-1779) yang selain sebagai sastrawan ia juga amat terkenal dengan penelitiannya di bidang listrik dan botani (Numata Jiro et al. 1986: 27-32).

Pada akhir abad kedelapan belas kekhawatiran Jepang terhadap pengaruh agama Kristen mulai berkurang, sehingga kesempatan dan minat mempelajari rangaku meningkat pesat. Dengan perkembangan tersebut, memasuki abad sembilan belas banyak penulis Jepang baik dalam bidang sastra, kesenian, dan ilmu pengetahun yang dipengaruhi pengetahuan dari Barat.

Dalam bidang kedokteran yang menjadi pelopornya adalah Sugita Gempaku (1733-1817). Sejak belia ia sudah akrab dengan buku-buku kedokteran dari Cina. Ketika ada kunjungan tahunan orang-orang Belanda ke Edo, ia mendapat kesempatan bertanya mengenai ilmu kedokteran Barat kepada mereka. Sejak itu mulailah ia mempelajari ilmu bedah Belanda melalui dokter-dokter Belanda yang tinggal di pulau Dejima. Namun, ia tidak merasa puas dengan apa yang ia dapatkan. Ia pun lantas berambisi untuk menciptakan ilmu bedah yang lebih baik dengan memadukan metode pengobatan Jepang, Cina, dan Belanda. Ia berusaha mengumpulkan data dengan mengunjungi orang-orang Belanda dan lebih mendalami ilmu kedokteran Barat yang ditulisnya dalam buku Youka Taisei (1757). Dalam bukunya tersebut antara lain ia menulis tentang ilmu kedokteran Barat mengenai cara pengangkatan tumor di dada, cara penghentian pendarahan, dan sebagainya (Numata Jiro et al. 1976: 614).

Pada tahun 1771 bersama Maeno Ryotaku dan Nakagawa Junan, Gempaku berhasil melakukan otopsi mayat perempuan berusia sekitar 50 tahun, kemudian membandingkannya dengan gambar-gambar dalam buku Anatomische Tabellen (Tabel Anatomi Tubuh) karya dosen kedokteran dari Leipzig, Johan Adam Kulmus (1689-1745). Ia merasa kagum mendapati akurasi gambar-gambar dalam buku itu, yang amat berbeda dengan ilmu pengobatan tradisional Cina. Mereka bertiga berusaha menerjemahkan buku tersebut ke dalam bahasa Jepang, dan kemudian diterbitkan dengan judul Kaitai Shinshou (1774). Gempaku juga mengungkapkan pentingnya buku tersebut dan ilmu pengetahuan Barat. Ia menyadari bahwa yang ia lakukan sebelum melakukan otopsi tersebut masih sangat tertinggal dan belum menyentuh masalah penerapan teori dalam pembedahan. Gempaku dapat dikatakan sebagai peletak dasar ilmu kedokteran modern di Jepang. Dengan diterbitkannya 
Kaitai Shinshou, yang memberi kontribusi besar terhadap perkembangan ilmu kedokteran di Jepang, pengajaran rangaku semakin meluas, tidak hanya di Nagasaki, tetapi juga di Edo. ${ }^{14}$

Tokoh rangaku lain adalah Otsuki Gentaku (1757-1827). Ia adalah murid Gempaku yang berjasa mengumpulkan tulisan-tulisan Gempaku yang kemudian dirangkumnya dalam buku Rangaku Kaitei, yang berarti tahapan dalam rangaku pada tahun 1788. Buku yang terdiri dari dua jilid ini amat penting, karena berisi pedoman bagi yang ingin belajar rangaku. Selain berisi pelajaran bahasa Belanda, buku ini juga memuat perlunya belajar bahasa asing, sejarah rangaku, dan pentingnya berdagang dengan Belanda (Goodman 1986: 121).

Rangaku berhasil membuka mata masyarakat Jepang bahwa mereka tidak harus selalu berorientasi ke Cina dan terpaku pada prinsip konfusianisme. Gempaku membalikkan pandangan bahwa tidak semua ilmu dari Cina dapat diterima begitu saja dan dianggap yang terbaik. Sebelumnya, masyarakat kedokteran di Jepang didominasi oleh ilmu pengobatan dari Cina, atau kampou igaku. Gempaku sangat mementingkan pengetahuan mengenai anatomi tubuh manusia dan patologi. Ia mendapati bahwa ilmu kedokteran Barat mampu menjelaskan proses yang terjadi di dalam tubuh secara sistematis dan ilmiah, misalnya tentang proses pencernaan makanan dan peredarannya ke seluruh tubuh serta kaitannya dengan munculnya penyakit. Setidaknya ilmu kedokteran Barat yang disebarluaskan Gempaku menjadi alternatif dalam dunia pengobatan di Jepang masa itu.

Jika kekuasaan didefinisikan sebagai kemampuan untuk mempengaruhi atau mengatur pikiran dan tingkah orang lain, maka sangat menarik untuk mencermati konstelasi kekuasaan dalam hubungan Jepang-Belanda ini dalam kerangka berpikir Foucault (1977 dan 1997). Seperti telah disebutkan sebelumnya pemerintah bakufu sudah berupaya mengukuhkan hegemoninya melalui kebijakan-kebijakan, misalnya sakoku. Pihak Belanda, dalam hal ini VOC, banyak mendapatkan pembatasan oleh pemerintah bakufu. Tetapi dengan semakin berkembangnya rangaku, pelan-pelan Belanda mulai berhasil menebar pengaruhnya melalui kaum cendekiawan. Bagi Foucault (1977: 27) kekuasaan menyebar di mana-mana (power as omnipresent), meresap dalam seluruh jalinan relasi-relasi sosial. Kekuasaan tidak berpusat pada individuindividu ataupun negara, melainkan bekerja, beroperasi dalam konstruksi pengetahuan. Karena ia menyebar dan bekerja mengendalikan banyak orang, kelompok, kepentingan, dan sebagainya, maka sifatnya menjadi produktif,

$14 \quad$ Tentang rangaku lihat Akagi Akio (1980), Inoue Kiyoshi (1973), Kato Fumio (1999), dan Sakai Shiji (2004). Mereka membahas aktivitas ilmuwan Barat yang datang bersama VOC. Akagi, misalnya, salah satunya menyoroti Philip Franz Balthasar von Siebold (17961866) ilmuwan Jerman yang mengajarkan ilmu kedokteran, dan sebagai imbalannya ia mendapatkan pengetahuan dan spesimen hewan dan tumbuhan dari orang-orang Jepang. Siebold diindikasikan sebagai mata-mata sehingga ia diusir ke luar Jepang ketika ketahuan memiliki peta Jepang. Inoue lebih menyoroti perkembangan ilmu pengetahuan alam di Jepang, sedangkan Kato dan Sakai mengulas sejarah rangaku secara umum. Kato juga mengulas Gempaku dan berbagai kendala dan yang dihadapi para pendahulu yang memulai rangaku di Jepang termasuk juga kegembiraan mereka. 
bukan represif dan memiliki kemampuan menormalisasikan hubungan dalam masyarakat, dan bekerja melalui mekanisme sosial. Rangaku menjadi media dalam hubungan antarjaringan sosial, komunikasi, meresap dan melekat pada perbedaan dan kehendak dari individu ataupun kelompok. Rangaku dalam istilah Foucault menjadi semacam micro pouvoirs, atau gugusan kekuasaan lokal yang tersebar. Di sini terlihat adanya hubungan kepentingan dan fungsional antara kekuasaan dan pengetahuan.

Seiring berkembangnya rangaku, banyak buku diterjemahkan, seperti teori fisika dan matematika. Banyak orang yang dengan sungguh-sungguh mempelajari bahasa Belanda. Para penerjemah menduduki posisi penting dalam hubungan Jepang-Belanda. Belanda juga memperkenalkan bendabenda mutakhir seperti barometer, teropong, jam, meriam dan sebagainya yang belum pernah dikenal masyarakat Jepang sebelumnya.

Berdasarkan uraian di atas dapat diketahui bahwa rangaku yang masuk bersama pedagang VOC ke Jepang lambat laun menyebar luas, baik secara bidang ilmu maupun daerah penyebaran, khususnya di kalangan cendekiawan. Hal ini tentu saja meningkatkan kepercayaan pemerintah bakufu kepada orang-orang Belanda termasuk para pedagang yang pada awalnya sempat dikhawatirkan akan berdampak kurang baik seperti agama Kristen yang dibawa para pedagang Portugis. Ini merupakan contoh yang tepat dari pendapat Gramsci (1971) yang menyatakan bahwa dominasi kekuasaan tidak hanya bisa diperjuangkan lewat kekuatan senjata, tetapi juga melalui penerimaan publik (public consent). Rangaku menjadi kekuatan bagi VOC agar dapat tetap diterima dan eksis, juga merupakan alat untuk mengurangi tekanan dan penyeimbang kekuasaan pemerintah bakufu.

\section{Perdagangan VOC-JePAng}

Sebelum memulai perdagangan dengan bangsa Eropa, Jepang sudah lebih dahulu memiliki hubungan dagang dengan negara-negara Asia, seperti Cina, Korea, Vietnam, dan Indonesia. Bahkan hubungan dagang dengan Cina sudah terjalin secara resmi sejak tahun 1401.

Agar Belanda loyal terhadap Keshogunan Tokugawa, mereka diberi status khusus seperti daimyo (tuan tanah), agar dapat memberikan upeti langsung kepada Shogun. Sudah merupakan kebiasaan bahwa setiap tahun daimyo harus mengunjungi Edo (Tokyo) secara bergantian untuk menyerahkan upeti. Kewajiban yang disebut dengan Sankinkotai ini dibuat tertulis untuk mewajibkan para daimyo menunjukkan loyalitasnya. Kunjungan ke ibukota yang oleh orang Belanda disebut dengan De hofreis naar Edo ${ }^{15}$, ini merupakan satu-satunya kesempatan untuk mengetahui berbagai hal tentang Jepang di luar Nagasaki. Selain itu juga merupakan kesempatan bagi warga Jepang untuk mengetahui keberadaan dan aktivitas Belanda di Jepang dan sekaligus dunia Barat (Goodman 1986: 25).

15 Dalam bahasa Jepang disebut Edo Sanpu, yakni kewajiban bagi para daimyo dan orang-orang Belanda di Dejima berkunjung ke ibukota, Edo, sebagai bentuk penghargaan dan menunjukkan loyalitas pada pemerintah bakufu. 
Dua kapal dagang VOC berlabuh pertama kali di Hirado, pulau kecil di pantai barat Kyushu, pada tanggal 2 Juli 1609, yakni kapal De Rode Leeuw met Pijlen dan De Griffioen. Di antara awaknya terdapat saudagar besar Abraham van den Broek dan Nicolaas Puyck, yang kemudian mengunjungi istana Shogun Tokugawa Ieyasu untuk meminta izin mendirikan kantor dagang Belanda di Hirado. Pada Agustus 1609 mereka menperoleh izin tersebut, dan diperkenankan berlabuh di semua pelabuhan di Jepang. Sebagai kepala perwakilan VOC di Jepang ditunjuk Jacques Speck. Dengan adanya kantor perwakilan ini perdagangan menjadi lancar, dan setiap tahun sekitar empat sampai tujuh kapal Belanda tiba dari Batavia ke Jepang.

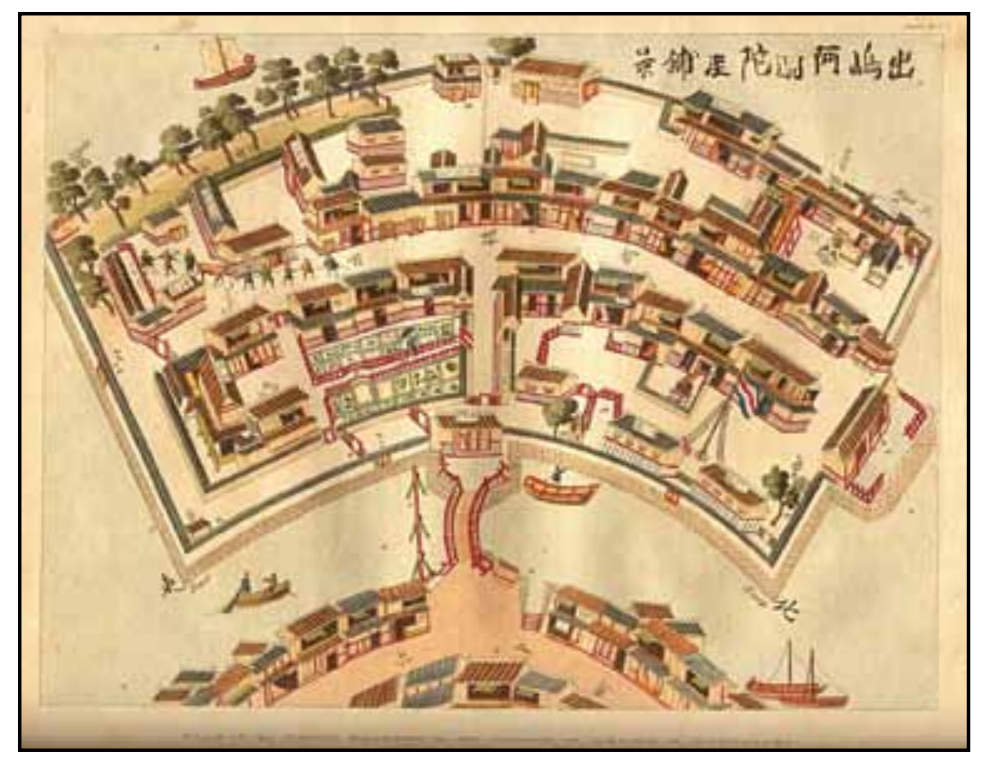

Ilustrasi 3: Gambar Pulau Dejima di Teluk Nagasaki. ${ }^{16}$

Ieyasu meninggal pada tahun 1616 dan digantikan oleh Hidetada, yang pada tahun 1923 digantikan oleh Tokugawa Iemitsu. Pada masa inilah Jepang menerapkan sakoku yang diikuti pengusiran orang asing selain orang Belanda setelah terjadinya peristiwa Shimabara. Posisi Belanda di Jepang menjadi istimewa karena permusuhan yang terjadi antara Belanda dengan Spanyol dan Portugis. Para pedagang VOC hanya sibuk berdagang dan tidak berusaha mengkristenkan penduduk Jepang. Mereka pun mampu meyakinkan penguasa bahwa Protestan berbeda dengan Katolik, dan dibuktikan dengan dukungannya dalam perang melawan pemberontak di Shimabara. Iemitsu melarang simbol-simbol agama kristen seperti salib, patung Bunda Maria atau Yesus. Di dalam kapal Belanda yang datang pun tidak ditemukan pendeta dan

16 Pulau yang dibangun di teluk Nagasaki tahun 1636 ini hanya seluas sekitar satu hektar. Semula diperuntukkan bagi perdagangan dengan Portugis, tetapi Belandalah yang kemudian menikmati fasilitas ini. Sumber: Titsingh: illustrations of Japan. London 1822. Diakses 28 Juni 2008 dari: http://flcsvr.rc.kyushu-u.ac.jp/ michel/serv/eujap/voc/dejima/1822.html. 
salib. Demi monopoli perdagangan di Jepang mereka berusaha mengambil hati pemerintah bakufu, dengan berlaku sopan dan memberikan upeti kepada para pejabat. Berbagai macam upeti yang dipersembahkan misalnya berupa kain dengan kualitas baik dari Belanda dan rempah-rempah dari Hindia Timur (Indonesia). Pihak Jepang semakin bersimpati kepada Belanda dengan adanya rangaku, yang ternyata membawa manfaat bagi masyarakat Jepang. Rangaku selanjutnya mendapat dukungan penuh dari pemerintah bakufu. Pemerintah bakufu juga terbantu secara ekonomi karena mengambil cukai dari perdagangan dengan Belanda.

Meskipun pemerintah bakufu mendukung keberadaan Belanda di Jepang, mereka membuat peraturan bahwa kepala perwakilan VOC hanya boleh tinggal selama satu tahun di Jepang. Hal ini antara lain untuk mencegah mereka menguasai bahasa Jepang, sehingga yang dapat menjadi penerjemah hanya bangsa Jepang saja. Dengan demikian diharapkan pengaruh kebudayaan asing dapat dibatasi agar tidak berkembang luas sehingga mudah dikontrol.

Meskipun Belanda sudah menunjukkan loyalitasnya pada bakufu dalam perang di Shimabara, Jepang tetap bersikap hati-hati terhadap mereka. Pemerintah bakufu mengeluarkan peraturan bahwa semua perempuan Jepang yang menikah dengan orang Belanda atau orang Inggris diharuskan pindah ke Batavia beserta anak-anaknya. Hubungan laki-laki Belanda dengan perempuan Jepang dilarang, kecuali dengan tuna susila. Meskipun demikian sejak era sebelumnya, yakni William Adams, awak kapal De Liefde yang mendarat tahun 1600, menikah dengan perempuan Jepang, dan tinggal di Jepang hingga akhir hayatnya. Sedangkan perempuan Belanda sangat sedikit yang datang ke Dejima.

Setelah diterapkannya sakoku dan pengusiran orang Portugis dari Dejima pada tahun 1639, maka pada tahun tahun 1641 orang-orang Belanda ditempatkan di pulau tersebut. Sebenarnya tujuan pemindahan ini adalah untuk mempermudah pengawasan terhadap orang-orang Belanda, tanpa perantara daimyo di Hirado. Pelabuhan Nagasaki juga lebih mudah diawasi.

Orang-orang Belanda menguasai rumah-rumah dan gudang yang ditinggalkan orang Portugis. Pulau ini dijaga ketat, dan orang-orang Belanda tidak bebas untuk keluar masuk, karena hanya dihubungkan sebuah jembatan dengan daratan, yang menjadi gerbang utama dan diawasi sangat ketat (lihat Ilustrasi 3). Orang hanya bisa melalui gerbang ini atas izin otona, pengawas tertinggi di pulau Dejima. Desain pulau Dejima pun dibuat agar mudah dikontrol. Misalnya saja saluran air dibuat sempit dan berkelok-kelok agar tidak dapat dijadikan jalur penyelundupan.

Sejak dilarangnya Katolik di Jepang, orang Belanda bersedia melakukan fumie, yakni tindakan menginjak-injak salib dan atribut keagamaan Kristen lainnya sebagai bentuk penolakan terhadap agama tersebut, seperti yang dilakukan penduduk Nagasaki. Hal ini merupakan reaksi dari peristiwa Shimabara. Belanda pun semakin mendapat simpati, tentu saja ini juga semakin memantapkan posisi VOC dalam monopoli perdagangan di Jepang.

Seluruh aktivitas perdagangan, seperti komoditas tekstil, tembaga, dan lainnya antara Jepang dengan Belanda dilakukan di Pulau Dejima. Kedua 
pihak memperoleh keuntungan besar. Para pegawai rendahan Belanda pun diizinkan melakukan transaksi perdagangan secara pribadi di luar agenda kantor dagang. Kebijakan untuk menambah penghasilan pegawai rendahan VOC ini, kerap kali disalahgunakan untuk menyelundupkan barang-barang, tetapi jika tertangkap pegawai VOC ini dikenai hukuman sesuai yang berlaku di negerinya, jika pelakunya orang Jepang maka hukumannya adalah penggal kepala, seperti yang pernah terjadi pada seorang penerjemah.

Pada periode Hirado (1600-1641) Jepang menjadi pasar potensial bagi sutra Cina, namun setelah itu Jepang mendapatkan sutra Cina melalui pedagang VOC. ${ }^{17}$ Selain tekstil, VOC juga menjual komoditas lain seperti kayu, rempah-rempah, gula, dan obat-obatan. Sedangkan Jepang mengekspor emas, perak, tembaga, dan kedelai. Pada periode Dejima, produk impor tersebut kemudian diangkut dengan kapal kayu dari Dejima menuju Edo. VOC mendapat keuntungan sangat besar melalui perdagangan ini. Namun, mulai tahun 1642 Jepang melarang ekspor logam mulia, dan ekspor tembaga dibatasi karena khawatir dengan cadangan yang ada, tetapi karena sangat menguntungkan, pada tahun 1660 ekspor komoditas ini dibuka kembali, dan dikirim ke Batavia.

Pada tahun 1672 Jepang mengeluarkan peraturan baru yang secara sepihak menentukan harga komoditas barang dagangan yang dibawa kapal VOC, khususnya dilakukan otoritas di Nagasaki, atau Nagasaki Bugyou. Jika pedagang Belanda tidak setuju dengan penawaran harga tersebut, mereka dipersilahkan membawa kembali barang dagangannya ke Batavia. Hal ini dapat diduga terjadi sebagai akibat kemarahan para pejabat bawahan Shogun di Edo yang tidak mendapat bagian upeti karena upeti diserahkan langsung kepada Shogun. Sebagai akibat dari kebijakan itu, tahun 1675 hanya empat buah kapal VOC yang merapat di Nagasaki. Di lain pihak, Jepang sebenarnya juga merasa khawatir seandainya Belanda, yang terkenal memiliki kekuatan angkatan laut hebat di perairan Asia akan memblokir kapal-kapal Cina yang akan memasuki Nagasaki.

Relasi kekuasaan antara Shogun-pejabat pemerintahan-VOC jelas terlihat sangat dinamis. Jepang yang "mengurung" Belanda di Pulau Dejima lama kelamaan menyebabkan terjadinya perdagangan yang tidak seimbang. Belanda lebih banyak dirugikan. Tetapi, dengan adanya rangaku Jepang juga menjadi tergantung kepada Belanda. Tahun 1682, VOC di Batavia melayangkan surat dalam bahasa Cina kepada Shogun Tsuneyoshi, yang mengkhawatirkan hubungan dagang Jepang-Belanda yang kian memburuk, dan meminta penghentian penentuan harga secara sepihak. Surat ini sengaja ditulis dalam bahasa Cina untuk menghindari salah penerjemahan oleh pihak Jepang, karena terkadang penerjemah Jepang tidak akurat dalam menerjemahkan. Nagasaki Bugyo tidak suka dengan tindakan Belanda yang langsung berhubungan dengan Shogun, dan ide penghentian penentuan harga sepihak yang justru akan menguntungkan VOC. Otoritas Nagasaki kemudian menaikkan pajak berbagai macam barang yang dibeli pihak VOC, termasuk

17 Mengenai komoditas ekspor Jepang melalui para pedagang VOC dapat dilihat dalam Iwao Seiichi (1974). 
manipulasi harga emas dan tembaga.

Pada tahun 1737 terjadi lagi perubahan, sejak itu bakufu menetapkan harga, atau pengiriman barang berdasar kontrak. Pihak Nagasaki Bugyou menentukan dulu daftar barang, kemudian pihak VOC mengirimkannya berdasarkan harga yang telah disepakati sebelumnya. Cara ini pun bermasalah di kemudian hari, karena pihak Belanda mengirimkan barang-barang bermutu rendah. Muncul saling ketidakpercayaan di antara kedua belah pihak, yang memicu ketegangan. Ketika terjadi perang Belanda-Inggris tahun 1780 penguasa bakufu tidak mengetahuinya. Jepang pun menunggununggu kapal VOC yang tak kunjung tiba. Isaac Titsingh, kepala VOC di Dejima sebenarnya mengetahui kondisi ini, dan memanfaatkannya dengan mengatakan kemungkinan VOC tidak mau berdagang lagi karena kecilnya keuntungan yang diperoleh.

Dalam kerja sama dengan VOC kekayaan alam Jepang seperti emas dan tembaga banyak terkuras. Di lain pihak, VOC pun mengeluhkan uang sewa di Dejima yang sangat tinggi, dan upeti yang harus dibayar kepada para penguasa. Selain itu muncul pula masalah pada tahun 1703-1706, yakni terjadinya kekacauan di Jawa, setelah Sultan Amangkurat II (berkuasa pada 1677-1703) dari kerajaan Mataram wafat. ${ }^{18}$ Pada tahun 1728 VOC di Batavia hampir memutuskan hubungan perdagangan dengan Jepang karena Belanda sedang menghadapi berbagai hal, namun dari hasil rekomendasi dewan pemerintah tujuh belas provinsi di Belanda (De Heren Zeventien) akhirnya opsi itu tidak jadi dilakukan. ${ }^{19}$

Meskipun yang menjadi fokus adalah perdagangan dan rangaku, tentu saja hubungan kedua negara tidak terlepas dari masalah kebudayaan, termasuk kesenian. Dalam bidang kesenian, justru pengaruh Jepang pada Belanda mulai tampak. Misalnya dalam seni keramik, Jepang sebelumnya meniru motif Cina dan mengembangkannya di Jepang. Belanda tertarik dengan motif yang dibuat seniman Jepang yang meniru motif Cina tersebut, dengan warna biru dan putih yang menjadi ciri khasnya. Motif inilah yang dipergunakan orang-orang Belanda, yang saat ini dikenal dengan Delft Blue. Sebaliknya, pada periode Dejima ini seni keramik Jepang kerap kali dihiasi huruf VOC.

Jelas, kedua negara mengambil keuntungan dari perdagangan di Dejima ini. Tetapi lebih dari itu Dejima menjadi “jendela" bagi Jepang untuk melihat Barat.

\section{PENUTUP}

Sejak agama Kristen dianggap sebagai ancaman terhadap persatuan bangsa dan diberlakukannya sakoku, Portugis dilarang berdagang di Jepang. VOC adalah satu-satunya bangsa Barat yang diperbolehkan berdagang di

18 Sewaktu dilakukan pemilihan pengganti Amangkurat II, saudaranya, yakni Pakubuwono I, tidak setuju dengan penunjukan putra sulung Amangkurat II sebagai pengganti ayahnya, menjadi Amangkurat III. Pakubuwono meminta bantuan Belanda, sehingga Belanda disibukkan dengan hal ini.

19 Banyak buku yang mengangkat hubungan Amangkurat II dengan VOC. Di antaranya Purwadi (2007); H.J. de Graaf (1989). 
Jepang, meski dibatasi hanya di pulau Dejima, Nagasaki. Komoditas yang diperdagangkan misalnya hasil tambang, seperti emas, embaga, perak, dan timah hitam. Selain itu rempah-rempah, kulit, kayu, gula, dan obat-obatan juga turut diperdagangkan. Secara keseluruhan, selama periode tahun 16411847 kapal Belanda yang masuk ke Dejima berjumlah sekitar 606.

Tidak selamanya hubungan Belanda-Jepang berjalan lancar, meskipun kedua negara awalnya saling mendapat keuntungan. Pada awal abad delapan belas Belanda mengalami kerugian cukup besar. Berbeda dengan Portugis dan Spanyol, Belanda yang tidak bermaksud menyebarkan agama Kristen di Jepang mendapat dukungan penguasa masa itu. Jepang tidak hanya mengambil keuntungan dari segi materi, namun juga dalam bidang ilmu pengetahuan dengan munculnya rangaku. Di tengah penerapan politik sakoku, rangaku mampu melunakkan sikap sebagian masyarakat Jepang terhadap Belanda, termasuk kaum cendekiawan.

Dengan politik sakoku, kelas samurai berusaha mengukuhkan hegemoninya terhadap kelas lain dengan berbagai cara. Dalam hubungan dagang dengan VOC pun, Jepang berusaha menjalankan perdagangan yang tidak seimbang, lebih banyak menguntungkan pihak Jepang. Pada era ini orang Jepang tidak diperkenankan melakukan perjalanan ke luar negeri, sehingga informasi tentang Barat hanya masuk melalui pedagang VOC. Orang Jepang pun diperkenalkan ke dunia luar juga melalui mereka. Jepang yang semula menyerap ilmu dari Cina, lambat laun beralih ke rangaku. Dengan rangaku, posisi Belanda terhadap pemerintahan bakufu semakin kuat, dan Belanda semakin mendapatkan kepercayaan kalangan lebih luas di Jepang.

Hubungan dagang kedua negara tidak hanya dipengaruhi hal-hal yang terjadi di Jepang saja, tetapi juga berbagai peristiwa yang terjadi di berbagai belahan dunia, baik Eropa ataupun yang terjadi di pulau Jawa. Pertempuran di Eropa yang dipimpin Napoleon Bonaparte pun turut mempengaruhi kondisi perdagangan kedua negara. Selain itu, kondisi di kerajaan pulau Jawa juga mengharuskan Belanda membagi perhatiannya. Bahkan perang di Amerika pada tahun 1776-1783 yang disokong pemerintah Belanda turut mempengaruhi pengiriman kapal dagang VOC ke Jepang.

Meskipun Belanda dibatasi hanya boleh beraktivitas di Dejima, bukan berarti pemerintah bakufu dapat "menguasai" dan menebarkan hegemoninya terhadapVOC begitu saja seperti yang dilakukan kaum bushi terhadap kelas sosial lainnya, terlebih dengan semakin meluasnya rangaku. Rangaku dalam skala tertentu selanjutnya menjadi semacam counter hegemony terhadap pemerintah bakufu. Maka, sangat menarik melihat hubungan dagang Jepang-VOC dan rangaku dalam sudut pandang atau konteks dan situasi seperti ini.

\section{DAFTAR PUSTAKa}

Akagi, Akio. 1980. Rangaku no Jidai. Tokyo: Chuo Shinsho..

Bourdieu, Pierre. 1990. Outline of a theory of practice. London: Cambridge University Press. 
Bourdieu, Pierre, and Jean-Claude Passeron. 1990. Reproduction in education, society, and culture. London: Sage Press.

De Graaf, H.J. 1989. Terbunuhnya Kapten Tack: kemelut di Kartasura Abad XVII. Diterjemahkan oleh Dick Hartoko. Jakarta: Grafiti Pers.

Foucault, Michel. 1977. Discipline and punish. New York: Pantheon.

Foucault, Michel. 1997. Seks dan kekuasaan. Jakarta: Gramedia.

Goodman, Grant K. 1986. Japan: the Dutch experience. London: Cambridge University Press.

Gramsci, Antonio. 1971. Selections from the Prison Notebooks of Antonio Gramsci. Quintin Hoare dan Geoffrey Nowell-Smith (red. dan penerj.). New York: International Publishers.

Huibert, Paul. 1984. Nederlanders in Japan 1600-1854: de VOC op Desjima. Weesp: Fibulan-Van Dishoeck.

Inoue Kiyoshi., et al. 1973. "Rangaku no Hattatsu To Kagaku Gijutsu", Nihon Bunkashi Taikei. Vol. 6. Tokyo: Shogakukan.

Iwao Seiichi. 1974. Nihon no Rekishi: Sakoku. Jilid 14. Tokyo: Chuo Koronsha. Kato Fumio. 1999. Gakumon no Hana Hiraite. - Rangaku Jishi no Nazo wo Saguru. Tokyo: Shin Nihon Shuppansha.

Nishi Kazuo. 2004. Nagasaki, Dejima, Oranda Ikoku Jijō. Tokyo: Kadokawa Shoten.

Sakai Shiji. 2004. Surasura Yomeru "Rangaku Jishi". Tokyo: Kodansha.

Nakamura, Tadashi. 1970. "Shimabara no Ran ni kansuru Kousatsu", Kyushu Sangyo Daigaku Kyoyubu Kiyou Vol. 6: 1-21.

Numata Jiro; Matsumura Akira; Sato Shosuke. 1976. Yougaku-Nihon Shisou Taikei. Tokyo: Iwanami Shoten.

Numata Jiro, et al. 1986. Yougakushi Jiten. Tokyo: Nichiran Gakkai.

Purwadi. 2007. Sejarah raja-raja Jawa. Yogyakarta: Media Ilmu.

Simon, Roger. 1991. Gramsci's political thought: an introduction. London: Lawrence and Wishart.

Totman, Conrad. 1988. Tokugawa Ieyasu Shogun. Kyoto: Heian International Inc. 